\title{
South-South cooperation - policy and practice by the Export Import Bank of China
}

\author{
ATM Tariqul Islam ${ }^{1}$, Li Xiaoyun ${ }^{2}$ \\ ${ }^{I}$ PhD candidate, College of Humanities and Development, China Agricultural University, Beijing, PR. China \\ ${ }^{2}$ Professor and Dean, College of Humanities and Development, China Agricultural University, Beijing, PR. \\ China
}

\begin{abstract}
The half a century old concept of South-South cooperation got new momentum when northern cooperation weaken by the financial crisis and with the rise of south. Advanced southern countries such as China, India, Brazil, Russia and South Africa are advocating actively for south to south cooperation through their increasing aid, investment and trade. Among the southerners China headlined more with its fast growing economic strength and pouring financial assistance to southern developing countries through aid, trade and investment notably in Asia. Most of these financing are improving necessary infrastructures, increasing productive capacity and contributing to economic growth. But there are gaps in policy and practice while competing for benefit from business initiatives. This is affecting quality of South-South cooperation. In the case of Bangladesh this study found that the environmental guideline of Chinese government is not carefully considered by Exim Bank ${ }^{1}$ of China in some projects. This paper suggests that the effort needs to be strengthened by the southern governments for getting better result from South-South cooperation. The aspects of competitiveness and complementarity, conceptual clarity and scope of cooperation should be discussed continuously.
\end{abstract}

Keywords:South-South Cooperation, China, Bangladesh, Exim Bank of China, Environment

\section{Introduction}

The South is not homogenous; it is very much diverse and intercontinental. It has diverse experiences and different struggling background. Enriched diversity of south is valuable in shaping development strategy for the developing countries. But there is a lack of uniformity to clarify the definition of South-South development cooperation. Many researches have been done to clarify the concept and definition of South-South cooperation but yet most of them are inconclusive. Over the last decades the concept of South-South Cooperation has drawn attention in global development discussions. It got more attention when many of the southern developing country's economic and political power become more visible and influential. Among the southerners China brought itself in the centre of discussion by appearing as the second largest economy and challenging the traditional foreign aid and investment monopoly of northern developed countries. Foreign aid as a tool of international development assistance generally understood in the context of North-South cooperation. It is seen as a transfer of capital resource, technical skill from developed North to poorer South (The Reality of Aid). Southern advanced developing country's confidence strengthened further and fueled South-South cooperation by Goldman Sachs's concept of BRIC economies consisting Brazil, Russia, India and China and their potential power and influence. Goldman Sachs predicted that China will become world's largest economy by 2030 and total BRIC economy will exceed the output of G7 nations (Alan Beattie 2010). The South-South cooperation is not a traditional aid mechanism since it developed in a context when aid become a neo-colonial tool of developed northern nations with policy conditionality and tied with commercial, political and defense strategy. Instead South-South cooperation developed based on solidarity and mutual benefit (The Reality of Aid). The scope of South-South cooperation is much broader and diverse than the scope of aid ${ }^{2}$ based cooperation. It consists of economic regions, multilateral institutions, strategic or political or military alliances etc. It also includes development cooperation in the form of technical cooperation, humanitarian assistance, concessional financing, trade and investment privilege etc. The 2008 Accra Agenda for Action (AAA) of the Third High Level Forum on Aid Effectiveness affirms that, "South-South cooperation on development aims to observe the principle of non-interference in internal affairs, equality among developing partners and respect for their independence, national sovereignty, cultural diversity and identity and local context. It plays an important role in international development cooperation and is a valuable complement to North-South cooperation (Accra 2008)". South-South cooperation has a long history since 1950 derived from the anti-colonial struggle of

\footnotetext{
${ }^{1}$ Exim Bank of China, Exim Bank and The Export Import Bank of China are same and these terms used interchangeably in this paper. ${ }^{2}$ Aid, Development Assistance, Foreign Aid - these terms are used interchangeably in this paper and considered only the financial flow from the donor government not the aid through NGOs
} 
developing nations. It expanded the horizon in continents (Africa, Asia) from Bandung conference in 1955 "on the basis of mutual interest and respect for national sovereignty" and widened further through Non Aligned Movement in 1961 (Bandung 1955). The south-south cooperation slept for while after the Bandung declaration but it returned to global discussion with the rise of India and China as a southern economic power. "China and India doubled per capita economic output in less than 20 years - a rate twice as fast as that during the Industrial Revolution in Europe and North America" (Roca, T. 2013, UN HDR 2013). Development assistance under South-South cooperation is contributed by different southern institutions and developing countries for almost half-a-century. The Kuwait Fund for Arab Economic Development (KFAED) is the first such fund in south established in 1961, with the Islamic Development Bank (IsDB) and Arab Bank for Economic Development in Africa (BADEA) is working since mid-1970s (Johnson Alison et al, 2008). But with the accumulated economic resources and desire of global leadership notably China is farahead in financing developing countries in the south. It has taken steps to establish full-fledged development cooperation agencies (Exim Bank, CDB, InternationalPoverty Reduction Centre etc.) and broadening the focus from mainly technical cooperation to more comprehensive development program.China's some initiative thus expanded beyond the trade and investment. "In promoting South-South co-operation between China and other developing member countries of the International Fund for Agricultural Development (IFAD), China's ministry of foreign affairs and IFAD have so far organized two south-south events, in September 2009 and November 2010 respectively" (UNDP 2011). In the third event senior officials from China and 15 developing countries from Asia and Africa attended. These initiatives of south are inspiring but need to set good example for creating win-win solutions. It is essential that the investments from south to south serve local needs better and strengthen production capacity. To promote successful south-south co-operation deeper understanding and analysis is required on policies in practice, institutional conditions and the right environments.

To dispel the misconception about South-South cooperation, evidence based analysis could help. Not only the good practices and aspirations but also the limitations need to be analyzed. This paper considers two Asian countries, China and Bangladesh, to look at the policies and practice in southern financing relationship. Though there are many other institutions of China are involved in Chinese development assistance but in the case of Bangladesh, China Exim Bank is the official channel for financing. On the other hand China's sheer share of development assistance is handled by the Export Import Bank of China. Thus this paper examines

- How China defines development assistance that contributes to South-South development cooperation

- The scope, type and allocation of South-South development cooperation flows to Bangladesh

- The quality of South-South development cooperation based on implementation of Chinese government's environmental policy guideline by the Export Import Bank of China in Bangladesh

The findings will help the policy makers to identify the weaknesses of South-South cooperation and reduce the gaps for better result. The findings were based on interview key government officials, project site visit and mostly relevant literature review.

\section{Definition of China's South-South Cooperation and ChineseDevelopment Assistance}

China is not a member of $\mathrm{OECD}^{3}$ thus it does not require complying with the DAC ${ }^{4}$ requirements for its foreign aid. Hence to analyze China's foreign aid should not be looked through the OECD definition of foreign aid or development assistance. China has its own guideline defined by eight principles introduced by Premier Zhou Enlai in 1964. By nature Chinese aid is not asperceived by northern ${ }^{5}$ donors, it is can be categorized as economic development investments in developing countries because it has both the development and business elements. It is secured by bilateral official agreements, that reduces the financial risks of the Chinese companies involved but it does not result Chinese ownership on foreign assets (Lengauer, Sara 2011). In China's white paper it is also named as "economic aid" instead of simply aid (White Paper 2011). The term "development assistance" can be applied as well for Chinese aid since it is a mechanism for economic development cooperation though financing productivity based projects. Ideologically Confucian belief has influence on Chinese foreign aid policy. According to Confucius ${ }^{6}$ main goal of the government is to achieve a world of peace and harmony (C. Hsu, 1991). This world of peace can be built by developing relationship with other communities in the world (C. Chen \& Y. Lee, 2008). China develops this relationship with its recipient country in a friend to friend manner (Lengauer, Sara 2011) instead of hierarchical donor-recipient relationship. This philosophical influence from Confucianism and eight principles of Chinese foreign aid articulates the modality of China's South-South cooperationas well as its development assistance, investment and trade with other

\footnotetext{
${ }^{3}$ OECD - Organization for Economic Cooperation and Development

${ }^{4}$ DAC - Development Assistance Committee

${ }^{5}$ Northern donors - Developed countries in the Europe and USA

${ }^{6}$ Confucius - Ancient Chinese philosopher
} 
countries. China's white paper on foreign aid also echoed that "as an important member of the international community, China will continue to promote South-South cooperation ... and make unremitting efforts to build, together with other countries, a prosperous and harmonious world with lasting peace" (White Paper 2011). By saying that, China takesSouth-South cooperation as one of the key driving factors of its international cooperation and creates distinctiveness. This papercharacterizestheChina's development assistance in promoting south-south cooperation in threecategories and those are:

1. Mutual economic benefit through economic assistance

2. Building relationship with developingcountries in the south

3. Reciprocation of non interference in internal matters ${ }^{7}$

\section{China's experiential learning on mutual benefit policy}

There is a fundamental difference between the rise of north and rise of south. Northern development was based on industrial revolution and in a context where private entrepreneurship was the driving force. In contrary there was no industrial revolution back rise in south. In China it started under public entrepreneurship (mainly state owned enterprises and government departments) after communist revolution. In a post war situation the then leadership concentrate on the infrastructural and industrial development as part of national economic development strategy. Infrastructures such as steel plants, chemical plants, and dams were prioritized in the five year plan with resources support from the former Soviet Union. Later in 1960 with the decline of Soviet support China was forced to explore its own resources for implementing national strategy and adopted the principle of 'self-reliance'. But the process slowed down due to lack of capital and technology. New technology import was thwarted by foreign currency shortage caused by long term trade deficit. In 1980s, this threshold forced China to utilize its mineral resources (mainly coal) to convert them economic resource. Coincidentally Japan, as a resource-poor country was hit by the 1973 oil crisis and was searching for new energy sources. That developed a win-win partnership between Japan and China. It helped China to convert its coal reserves into useable fuel for economic development and achieve self reliance strategy. This is a great leaning for China as a development approach. China embedded this experiential learning into it's development assistance approach. Gradually China adopted the policy of 'reform and opening up to the outside world' in late 1978 and Japan received its first official assistance from Japan. Japan's assistance was through various schemes such as yen-loans by Overseas Economic Cooperation Fund (OECF), bank loans for resource development by Export-Import Bank of Japan (JEXIM), technical assistance and grant assistance. Japanese assistance added value to China's untapped mineral reserves and converted those to foreign currency reserve. That laid the foundation of today's China's development assistance power and approach of mutual benefit (Kobayashi) framed in South-South Cooperation. With leaning from Japan's assistance China aided the massive Tanzam railway ${ }^{8}$ construction project, the largest overseas development assistance in Chinese history demonstrates its political interest in collaborating with postcolonial states in Africa through a non-Western model of development (Fahimul Quadir, Apr 2013). In Angola it supported the country to convert oil resources to capital resources for economic development. The model was not unquestioned by the northern countries as natural resource extraction always create environmental problems. However experimental Angola model ${ }^{9}$ built the confidence of Chinese for going ahead with their self define model of mutual benefit among southern countries. It is not grouped with traditional donors as it opposes their hierarchical donor-recipient relationship and promotes south- south cooperation with horizontal relationship.

\section{China's South-South cooperation and role of The Export and Import Bank of China}

It is difficult to pinpoint that directly or indirectly how many government departments or ministries are involved in Chinese overseas financing (Figure 1). Usually it depends on the category of the financed project. Despite the involvement of many entities the Exim Bank of China plays a key role and directly linked with government and overseas business activities operated by Chinese companies following the eight principles of Chinese aid.

\footnotetext{
${ }^{7}$ Internal affairs - politics, governance, accountability, transparency etc.

${ }^{8}$ Tanzam Railway links the Tanzanian port of Dar es Salaam with the town of Kapiri Mposhi in Zambia's Central Province. It was financed and constructed by China during 1970-1975

${ }^{9}$ Angola model - Development model with oil back financing from China to Angola
} 
Figure: 1Channels of China's foreign aid assistance

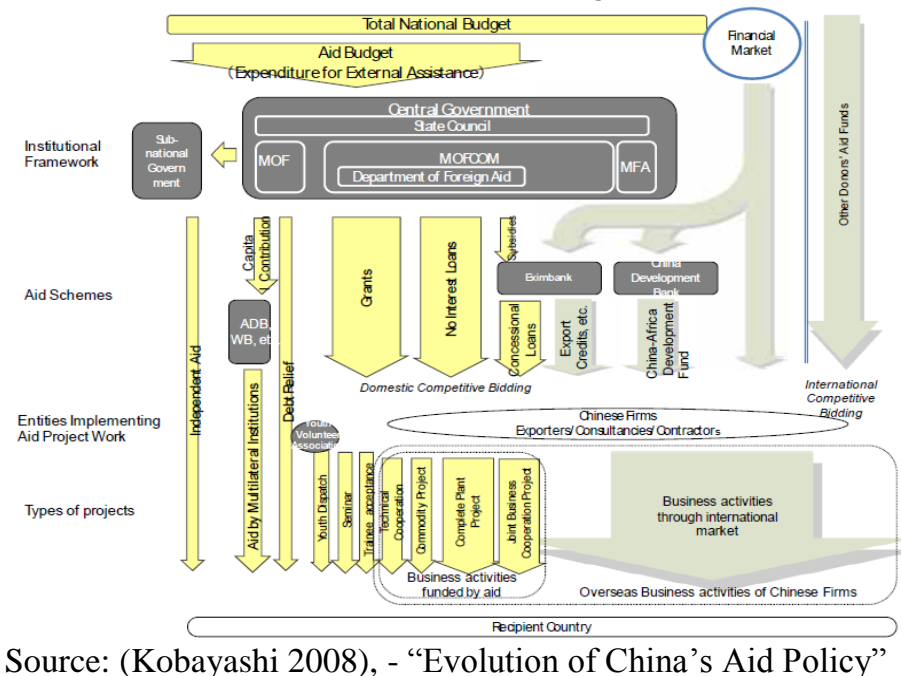

The Export-Import Bank of China (in Chinese Zhōngguó Jinchūkǒu Yínháng), commonly known as China Exim Bank, is one of three policy banks in China implement relevant state policies. Founded in 1994 and operates directly under the leadership of the State Council ${ }^{10}$. It is headquartered in Beijing with three representative offices in Africa, Paris and St. Petersburg. It also has more than 20 domestic business branches and correspondent banking relationship with more than 1,000 banks.

Main objectives of the Bank is to facilitate i) the export and import of Chinese mechanical and electronic products, equipments, high-tech products, ii) assist Chinese companies with comparative advantages in their offshore project contracting and outbound investment, and iii) promote international economic cooperation and trade (Exim Bank 2013). It also has commercial operations and that includes export credits, preferential buyer's credit for infrastructure projects (roads, power plants, oil and gas, telecom, and water projects etc.) and investment loans for Chinese businesses (Jian Ye Wang 2007). Through Table 1 we can identify the China Exim Bank's objective those are derived from eight principles of Chinese foreign aid.

Table: 1China's eight principles of foreign aid and objectives of China Exim Bank

\begin{tabular}{|l|l|}
\hline \multicolumn{1}{|c|}{ Alignment of China Exim Bank's objective with Chinese foreign aid principle } \\
\hline \multicolumn{1}{|c|}{ Eight principles of Chinese Foreign Aid } & Objective of Policy Banks (China Exim Bank) \\
\hline $\begin{array}{l}\text { Equality and mutual benefit in providing aid to other countries. It } \\
\text { never regards aid as a unilateral gift. }\end{array}$ & \\
\hline $\begin{array}{l}\text { Help recipient countries for their self-reliance and independent } \\
\text { economic development }\end{array}$ & \\
\hline $\begin{array}{l}\text { Technical assistance will help the personnel of the recipient } \\
\text { country to fully master the technology }\end{array}$ & \\
\hline Business aspect & Promote international economic cooperation and trade \\
\hline The forms of economic aid interest-free or low-interest loans, & $\begin{array}{l}\text { Help recipient countries to increase their income and accumulate } \\
\text { capital }\end{array}$ \\
\hline $\begin{array}{l}\text { Provides the best-quality equipment and materials manufactured } \\
\text { by China at international market prices those are needed for the } \\
\text { projects }\end{array}$ & $\begin{array}{l}\text { Facilitate the export and import of Chinese mechanical and } \\
\text { high-tech products }\end{array}$ \\
\hline $\begin{array}{l}\text { The experts from China will have the same standard of living as } \\
\text { the experts of the recipient country }\end{array}$ & $\begin{array}{l}\text { Assist Chinese companies with comparative advantages in } \\
\text { their offshore project contracting and outbound investment }\end{array}$ \\
\hline Diplomatic aspect & \\
\hline $\begin{array}{l}\text { Respects the sovereignty of recipient countries and attaches no } \\
\text { conditions. }\end{array}$ & \\
\hline ** (Table developed by author based on own understanding from different sources) \\
\hline
\end{tabular}

Chinese aid policy guideline has 3 aspects development aspect, business aspect and diplomatic aspect. Table 1 show that Exim bank's main objectives aligned business aspects, so rest of the aspects lies on directly with the Chinese government's effort and relationships. In Bangladesh Chinese supported projects are on power plant, road and bridge construction, fertilizer factory, telecommunication infrastructure, Supported by Exim Bank's loans Chinese companies as contracting agencies also play important role in arranging or negotiating for the loans either in the form concessional loans, hard loans or supplier's credit. In Bangladesh Chinese companies

\footnotetext{
${ }^{10}$ State council - China's highest decision making body
} 
first consult with the relevant ministries or departments for the projects those are in the annul plan of the departments. Once the primary negotiation is done then the companies helped the relevant departments in getting concessional loans ${ }^{11}$ or buyer's credit from the Chinese government or Exim bank of China. In some cases these bank helped in getting loans from other commercial banks as well. So the successful cooperation relies on the need of the host countries department and the capacity of the contracting company's capacity in arranging loans from Exim bank.

\section{Practice of Mutual benefit policy in Bangladesh}

To understand the mutual benefit we took the joint statement made by Chinese premier and prime minister of Bangladesh. In 2010 Chinese government and Bangladesh government made the joint statement during the visit of Bangladesh prime minister to Beijing that describes the type of cooperation two countries hold. The key points sketched are (China Embassy in Bangladesh):

- Exchange high-level visits for government agencies, parliaments, political parties, armed forces, law enforcement departments and non-governmental groups (media organizations, think tanks, scholars, friendship groups, women's groups, cultural troupes, athletes and youths). Chinese government scholarships to students and young diplomats

- Intensify cooperation in trade, investment, agriculture, transportation and infrastructure development on the basis of equality and mutual benefit. Reduce trade imbalance and provide preferential tariff treatment to Bangladeshi products. Involvement of Chinese enterprises in the energy, communication, transportation, industry and infrastructure sectors in Bangladesh. Signed MOU on Cooperation in Oil and Gas Sector

- Commitment to continue to offer assistance to Bangladesh in support of the economic and social development of Bangladesh. Signed the Agreement on Economic and Technical Cooperation between the Governments, Framework Agreement on a Concessional Loan to Bangladesh for some infrastructures. Support enterprises for two-way investment and mutually beneficial cooperation, includes project contracting and labor service cooperation.

- Memorandum of Understanding on Agriculture Cooperation. Cooperation in hybrid rice cultivation technology, agricultural machinery technology, exchange of germ plasm resources of crops, farm products processing and technical personnel training

- Cooperation on hydrological data sharing and flood control of river Yarluzangbu/Brahmaputra, in view of its necessity to the disaster reduction in Bangladesh. Provide assistance for dredging of riverbeds. Agreed to hold consultations on climate change support Bangladesh in enhancing its capability to tackle climate change challenges

- Respects Bangladesh's independence, sovereignty and territorial integrity and Bangladesh reiterated that there is one China, the Government of the Peoples' Republic of China is the sole legal government representing the whole China, and Taiwan and Tibet are inalienable parts of the Chinese territory.

- Enhance cooperation with the SAARC ${ }^{12}$ and BCIM ${ }^{13}$ regional economic cooperation process. Also agreed to enhance transport links and, discuss the possibility of building road and rail links between the two countries.

The key economic benefits may derive from this statement of bilateral understanding are about trade and investment where Chinese companies will have more access to the market of Bangladesh and engage with the development projects. In return Bangladesh will get preferential trade treatment and support from the Chinese government for increasing the export led income.The Bangladesh will also acquire agricultural knowledge from the exchange and scholarships which would contribute to agricultural production capacity. This joint statement articulates the mutual benefit particularly in the area of reducing trade imbalance and preferential tariff treatment. But it is yet to see how much it contributes to the economy and in what quality. The statistics(Table 2) implied that it is not only the cooperation or privileges can have positive impact on the development but there is a necessity of cooperation for capacity enhancement for getting mutual benefit equally or equitably.

Table 2:Year wise export, import and trade deficit between China and Bangladesh

\begin{tabular}{|l|l|l|l|}
\hline \multicolumn{2}{|l|}{ Export-Import between China and Bangladesh } & \multicolumn{2}{l|}{$\begin{array}{l}\text { Trade deficit for Bangladesh } \\
\text { (Million USD) }\end{array}$} \\
\hline FY Year & $\begin{array}{l}\text { Export to China } \\
\text { (Million USD) }\end{array}$ & $\begin{array}{l}\text { Import from China } \\
\text { (Million USD) }\end{array}$ & -543.95 \\
\hline $1997-98$ & 48.51 & 592.46 & -549.86 \\
\hline $1998-99$ & 10.61 & 560.47 & \\
\hline
\end{tabular}

\footnotetext{
${ }^{11}$ Concessional loan - According to IMF guideline in Bangladesh if a loan has at least $35 \%$ grant element then it is considered as concessional loans.

${ }^{12}$ SARRC - South Asian Association for regional cooperation

${ }^{13}$ BCIM - Bangladesh, China, India and Myanmar regional forum
} 
South-South cooperation - policy and practice by the Export Import Bank of China

\begin{tabular}{|l|l|l|l|}
\hline $1999-00$ & 10.56 & 568.06 & -557.50 \\
\hline $2000-01$ & 11.67 & 708.94 & -697.27 \\
\hline $2001-02$ & 18.92 & 657.78 & -638.86 \\
\hline $2002-03$ & 19.50 & 779.50 & -760 \\
\hline $2003-04$ & 45.65 & 1132.72 & -1087.07 \\
\hline $2004-05$ & 56.07 & 1643.77 & -1587.70 \\
\hline $2005-06$ & 64.35 & 2078.99 & -2014.64 \\
\hline $2006-07$ & 92.97 & 2572.62 & -2479.65 \\
\hline $2007-08$ & 106.95 & 3136.70 & -3029.75 \\
\hline $2008-09$ & 97.06 & 3451.47 & -3354.41 \\
\hline $2009-10$ & 178.63 & 3819.28 & -3640.65 \\
\hline $2010-11$ & 319.66 & 5912.55 & -5592.89 \\
\hline $2011-12$ & 401.94 & 6433.21 & -6031.27 \\
\hline $2012-13$ & 458.12 & 6324 & -5865.88 \\
\hline \multicolumn{2}{|l|}{ Table made by author. Data source: Dhaka Chamber of Commerce and Industry (DCCI 2013) } \\
\hline
\end{tabular}

The export from Bangladesh to China has increased over the last decade but the total volume is yet to increase a lot. Statistics (Table 2) shows that the trade deficit between China and Bangladesh has not reduced.On the other the volume of trade deficit also increased around 10 times in 2013 compare with the total amount of deficit in 1997. It implies that either the preferential trade tariff was not utilized well or the capacity to export did not increase as it should be. The reason for this need to be researched but the fact is that equality in mutual benefit at least in the trade sector was not materialized from Bangladesh side. Thus in true sense perhaps there some other mechanism requires in getting appropriate benefit from south-south cooperation. Otherwise it may result the same as happened with the rich and developed northern partners and the spirit of South-South cooperation will be deviated from it desired track. If we examine the other southern rich partners such as India or countries in Middle East, scenario will not be much different. In the first ten months of financial year 2012-13, total trade gap of Bangladesh was at US\$ 5.55 billion against $\$ 7.53$ billion during same period of the previous fiscal year(FE 2013). Until February 2011, the import share of China in Bangladesh was $18.48 \%$ and India's share was $14.34 \%$. On the other hand share of export to China was around $1 \%$ and most of the export was towards northern countries (Kabir Mahfuz 2011). This is almost equivalent to the trade gap between China and Bangladesh; this means Bangladesh needs to balance trade from the earning from northern countries. Rich Southern partners could help the poorer southern partner in this regard.

Thekey areas identified for investment support are the mining, energy, telecommunication and infrastructure.This match with the Chinese development assistance provided in the form of supplier's credit. The chart below shows that most of the supplier's credit went to the energy sector such as power generation. This helped Bangladesh in increasing the power for supporting industrialization and agriculture. But it also helps Chinese companies to acquire knowledge and experience for international project implementation.

Figure 2: Sector wise allocation of Chinese supplier's credit

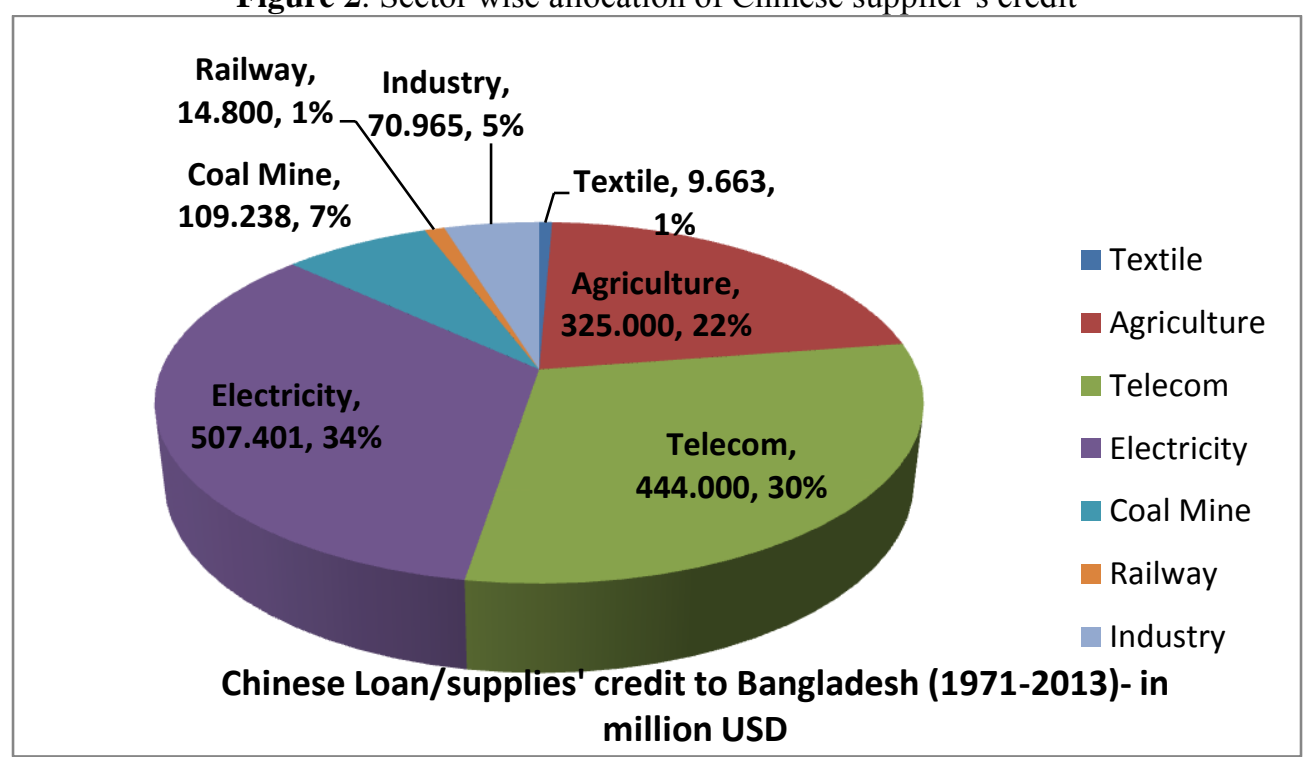

Source: Made by Author, Data: ERD, Ministry of Finance, GOB. 
Since the China aided (through suppliers' credit $^{14}$ )projects in Bangladesh are on infrastructure and are highly technical (Power plant 34\% and telecom 30\% and fertilizer factory/agriculture 22\%), it requires huge high tech equipments and accessories as well as technical experts. With foreignaid from China currently Bangladesh government is implementing six big projects (BSS 2013),

1. 7th China-Bangladesh Friendship Bridge on River Arial Kha,(constructed six friendly bridges before)

2. Shahjalal Fertilizer Factory project

3. Information communications and technology for introduction of $3 \mathrm{G}$ and expansion of $2.5 \mathrm{G}$ network

4. Padma Water Treatment Plant

5. Info Sarker (E-governance) and

6. Barapukuria Coal Mine Development Project and Barapukuria coal-fired power plant

These projects have contributed a lot in the power and telecom sector but italso increased the export of Chinese products and equipments in both investment and development assistance channels. Most importantly thejoint statement mentioned abovedoes not talk about the quality of projects such as environmental issues, people's rights protection issues. This creates the opportunities for companies and Exim Bank to ignore those issues as well as affect sustainability of the development cooperation.

The statement talks about other two characteristics of China development assistance to the southern countries. The interest and emphasis on SAARC and BCIM regional initiatives, exchange of scholars, people, media, non government and government groups are part of building relationship developing countries in the south.

The agreement on sovereignty and integrity of Bangladesh, recognition of one China, issue of Taiwan, Tibet are for reciprocation of non interference in internal matters. Though China is the largest trading partner of Bangladesh but it never engage in the regular political crisis of Bangladesh. It has never shown any concern about governance, corruption or reform in the country. It raised it's concern only two times when Taiwan taken an initiative for opening a consulate in Dhaka for issuing visa for enhancing business ties and the second one is a photo exhibition on Tibet issue.

\section{Environmental Policy guideline ofChinese government for projects abroad}

Ministry of Commerce of the People's Republic of China and Ministry of Environmental Protection of the People's Republic of China has issued policies on environmental protection in February 2013 for foreign investment and cooperation. The policies are formulated to further regularize the environmental protection behaviors in foreign investment and cooperation, guide to actively perform social responsibilities of environmental protection, and promote the sustainable development of foreign investment and cooperation by the Chinese institutions those are financing domestically and abroad.These Guidelines are applicable to the Chinese enterprises engaged in foreign investment and cooperation activities.

In summery the Guidelines for Environmental Protection in Foreign Investment and Cooperation are to (Islam, T. 2013):

- Regularize the environment related behaviors of Chinese companies in foreign investment and cooperation activities (Article 1)

- Guide for the performance in social responsibilities for environment protection (Article 1)

- Advocate to respect religious belief, cultural traditions, local customs of the community, safeguard legitimate rights and interest of labors (Article 3)

- Understand and observe host country's provisions of law and regulations related to environment protection. (Article 5)

- Conduct environmental impact assessment, take measures to reduce possible adverse impacts based on impact assessment (Article 8)

- Develop environmental monitoring and evaluation based on the background situation of project surrounding areas (Article 11)

- Formulate contingency plans for environmental accidents and other emergencies and set up reporting and communication system for local government, environmental regulatory authority, general public and company headquarters. (Article 14)

- Post their environmental information on a regular basis, and publish their plans on implementation of laws and regulations on environmental protection, measures taken, and environmental performance achieved(Article 18)

\footnotetext{
${ }^{14}$ Suppliers' credit - Credit given by Exim Bank of China to make the payment to Chinese contracting agencies for the projects implemented in Bangladesh. Term Export Buyers' credit is also used for the same purpose in this paper.
} 
- Establish communication and dialogue mechanism to strengthen their communications with their communities and relevant social groups, take opinions and suggestions with respect to environmental impacts of their construction projects according to requirements of laws and regulations of the host country. (Article 20)

- Encourage enterprises to research and learn from the environment protection related principles, standards and practices adopted by international organizations and multilateral financial institutions. (Article 22)

The Chinese government also introduced a "green credit" guideline for commercial lenders in 2012(CBRC 2012) to facilitate economic restructuring in a manner that's environmentally friendly and saves energy. The China Banking Regulatory Commission, the top banking regulator, ordered lenders to cut loans to industries with high-energy consumption and high levels of pollution, and to strengthen financial support for green industries and projects. The CBRC encouraged banks to evaluate, classify and rate the environmental and social risks inherent in their clients' businesses and take the results as a key reference in their ratings and access to credit. In future the CBRC will set up some key indexes to make the guideline more specific and try to include adherence to the plan in the rating system. Lenders also need to improve management of any overseas projects that they support, to ensure that the initiators of those projects comply with local environmental, land, healthcare and security legislation, according to the guideline (China Daily, 2012).

If we look at the terms of borrowing from Exim Bank there is no strong requirement on the environmental issue. The following requirements stated in the China Exim bank website, shall be satisfied when applying for Export Buyer's Credit:

- The economic and political environment of the borrower's country should be stable;

- The borrower should demonstrate sound credit standing and good debt servicing capacity;

- The value of the commercial contract shall exceed USD 2 million, and the export project shall fall into the financing area of this credit;

- The Chinese content of export products should be no less than $50 \%$ of the total contract value. For the overseas contracting projects, no less than $15 \%$ of the project shall come from the export of Chinese equipment,construction mechanics, materials, engineering work, technical and managerial expertise, and labor services;

- The borrower shall provide a repayment guarantee acceptable to the Bank;

- Export credit insurance shall be sought if required;

- Other requirements the Bank deems necessary

These requirements in related to the procedures encourage the contracting agencies to device their bank financed project as a commercially viable project rather than a socially and environmentally sensitive development project.

As mentioned earlier that one of the purposes of Chinese concessional loans is for export promotion though it mention about the economic development. According to the Chinese concessional loan's guiding procedures contracting Chinese firm should "purchase and import from China as much equipment, technology and services as possible". The host site should have "plentiful local resources, a vast market for goods, favorable economic prospects" (Paul Hubbard, 2007). When an investment is much more concerned about the market related elements such as export, import, purchase then it needs to be more concerned about profitability which reduces the concerns for social development or right protection related elements. Thus it's very difficult for the financing agencies such as China Exim Bank to promote or protect people's rights or environmental issues derived from the projects. It then relies only on the host country's effort and accountability mechanism. If the host country do not have strong mechanism or accountability or intention then there is huge potential of negative impact from the whole cycle the project and all stakeholders need to share the responsibility.

\section{Gaps in environmental policy practice}

As per global practice policy bank's job should be providing soft loans. Though Exim Bank does not provide commercial loans but in some cases the nature of the concessional loans provided by Exim bank is close to commercial lending considering the general practice of defining grant elements (interest rate, grace period, maturity period etc.) of loans provided by the Exim bank. When there is a commercial intention of any investment the potentiality of environmental ignorance or rights protection become very high. The profitability of the project targeted by the contracting agencies may loosen the control over environmental or rights protection bindings.

Though there are policies and regulations by the Chinese government for all the banks in China including Exim bank which should finance those companies protecting environment and people's rights, but this study found that the practices by the contracting agencies funded by Exim bank are sometimes not fully 
compliant. If we take the example of Barapukuria ${ }^{15}$ coal mine project and power plant project the following issues are yet to be settled (Islam, T. 2013):

- Barapukuria coal mine is still a controversial project.

- People in the affected area did not get proper compensation for acquired and subsidence land

- Labour rights are not yet properly protected

- Environmental disaster continues (Water pollution and decrease the ground water label causing water scarcity)

- Affected people's Movement is going on and government has not fully settled the issues with the people. Many people have been displaced without compensation.

- More coal is required, more areas are acquired for new mining phase and more people will be displaced

China Exim bank did not finance Barapukuria coal mine, it was financed by ICBC ${ }^{16}$ and Bank of China to the Chinese company named $\mathrm{CMC}^{17}$. CMC still getting funding from ICBC for various projects and it is not sure whether the track record of this company in Barapukuria coal mine has been evaluated as per the CBRC guideline or not. On the other hand Barapukuria coal fired power plant III has been contracted to another Chinese joint venture led by and $\mathrm{CCC}$ Engineering $\left(\mathrm{CCCE}^{18}\right)$. Barapukuria power plant III will require more coal extraction from the existing contradictory coal mine which will increase the environmental degradation in that area. CCCE has done lots of good projects in Bangladesh in particularly in the power sector and acquired huge experience in this sector. It will certainly engage with more projects in Bangladesh with its experience but before choosing a project like Barapukuria it could look at the environmental issues. Until the environmental degradation issues are not solved any company and its project linked with Barapukuria coal mine will share the responsibility of that environmental damage. By taking the Barapukuria coal fired power plant project CCCE's environmental sensitivity is questioned now. Because as per the Chinese government's requirement and guideline environmental assessment is required and need to be ensured that it is not risky for environment. Recently CCCE led joint venture become the contracting agency for Gazipur ${ }^{19}$ Kodda Thermal power plant financed by China Exim Bank and ICBC(CCCE website, ERD Bangladesh). This decision can be questioned as well since Exim Bank is not supposed to finance a company which potentially has negative track record in terms environmental issues.

\section{Transparency in selecting contracting agency}

The requirements for minimum 50\% Chinese export product, equipment, construction mechanics, materials, engineering work, technical and managerial expertise, and labor services for Chinese contracting agency and minimum $15 \%$ for overseas contracting agencies should go through a comprehensive and transparent selection process to ensure a responsible company. But the practice is slightly different. In the case of Bangladesh most of the projects are taken by consortium where a known company is forming consortium with comparatively smaller and less experienced companies those are trying to acquire international experiences and has intention to be an international company. In many cases these companies originate from former government departments or subsidiary institutions. Taking the example from a recent Chinese consortium called M/S CCCE-ETERN-FEPEC, took the contract of a power plant.According to CCCE company website Gazipur power plant project will be executed jointly by CCCE and Jiangsu Etern co. LTD. (ETERN), and Fujian Electric Power Engineering Company (FEPEC), thus the name of the joint venture become M/S CCCE-ETERN-FEPEC. ETERN and FEPEC have less or no experience in Bangladesh than CCCE (Islam, T. 2013). The concern here is to know the profile and environmental performance of these companies are very difficult since most of their key website information is in Chinese language and no information publicly available prior to their selection. From both points of view like unavailable information and strategy for growing by profit maximization and experience gathering there are scope for environmental and rights issues in the host countries.

\section{Conclusion}

In the face of global financial crisis South-South cooperation is bringing more options and choices for getting capital inflow and development financing from the rising southern development partners. The areas where northern traditional donors are reluctant to finance and tie with uncomfortable conditions, southern development partners are coming with their accumulated financial resources to support with a spirit of mutual benefit and no string attached. These financial supports are certainly helping the southern developing countries

\footnotetext{
${ }^{15}$ Barapukuria - a place in northern Bangladesh

${ }^{16}$ ICBC - Industrial and Commercial Bank of China

${ }^{17} \mathrm{CMC}$ - China National Machinery Import and Export Corporation (CMC)

${ }^{18}$ CCCE - A Chinese company

${ }^{19}$ Gazipur - a place near Dhaka, Bangladesh
} 
to boost their economic growth and development. But still there are gaps in spirit, policies derived from that spirit and the practices their institutions and business institutions involved in. In the case of China, the Export Import bank of China is key role player in such financing for taking forward the spirit of South-South cooperation. But this paper found that still there are gaps between the policies developed by Chinese government, particularly for environmental protection in the recipient countries, and the practice is the ground by the bank and the bank supported companies engaged in Bangladesh. The major gaps are in the area of:

1. Transparency in selecting contracting agency and their accountability, participation of recipients

2. Implementing the Chinese government's environmental protection policy

This paper suggests that if the following recommendations will be taken into consideration; the result from China's South-South cooperation will create best practice.

- Participatory and independent environmental impact and risk assessment need to be incorporated in the financing requirement. This should not be done by the government department only but could be joint report by government and external experts. Both assessment reports should be considered for financing decision.

- Direct or indirect engagement of recipient country should be considered in contracting agency and suppliers' selection process. The credibility rating and performance profile of the contracting agency need to share with the recipient country.

- Recipient country should have the information about the organizations if there is any black listed agency by the Chinese government or have weak performance related to environmental and people's rights violation.

- Should avoid to finance projects, those are controversial or disputed by the people or people's movement in the recipient country.

- It would be good to have penalty mechanism for the non complying companies, in PRC's environmental protection policy guideline (the policy guideline referred in this paper).

\section{Journal Papers:}

\section{Reference}

[1] Alan Beattie (2010). BRICS: The changing faces of global power, Financial Times, January 17, 2010 accessed at http://www.ft.com/cms/s/0/95cea8b6-0399-11df- a601-00144feabdc0.html

[2] Johnson Alison, Versailles Bruno, Martin, M., (2008). Trends in South South and triangular development cooperation, Backgournd study for Development cooperation forum,

[3] (Lengauer, B.S., 2011). China's Foreign Aid Policy : Motive and Method. , 9(2), pp.35-81

[4] C. Hsu. (1991). Applying Confucius Ethics to International Relations, Journal of Ethics and International Affairs, 5(March/April)

[5] C. Chen \& Y. Lee, (2008). Leadership and Management in China: Philosophies, Theories, and Practices, p.7

[6] (Kobayashi, Takaaki). China: From an Aid Recipient to an Emerging Major Donor.

[7] Fahimul Quadir, (2013). Rising Donors and the New Narrative of 'South-South' Cooperation: what prospects for changing the landscape of development assistance programmes?

[8] Kobayashi, Takaaki(2008). Evolution of China's Aid Policy JBICI Working Paper, no. 27

[9] Jian Ye Wang (2007). What Drives Chinas Growing Role in Africa Jian Ye Wang_wp07_211

[10] Paul Hubbard (2007). Aiding Transparency: What We Can Learn About China ExIm Bank's Concessional Loans)

\section{Proceeding/conference papers:}

[1] (The Reality of Aid). South-South Development Cooperation: A challenge to the aid system, The Reality of Aid Management Committee

[2] Accra (2008). (Also Cited in the Reality of Aid) Accra Agenda for Action accessible at http://www.accrahlf.net/WBSITE/EXTERNAL/ACCRAEXT/0,,contentMDK:21690826 menuPK:64861649 pagePK:64861884 p iPK:64860737 theSitePK:4700791,00.html

[3] Bandung (1955). Final Communiqué of the Asian-African conference of Bandung, 24 April 1955, accessible at http://www.ena.lu/final_communique asian-african conference bandung_24_april_1955-020000556.html

[4] Kabir Mahfuz (2011). Presented at Roundtable Discussion on Bangladesh-China Bilateral Relations, BIISS, Dhaka, 27 September 2011

Official website and reports:

[1] Roca, T. (2013). Human development Report 2013. The Rise of the South, Human Progress in a Diverse World. Afriquecontemporaine, 246(2), p.164. Available at:http://www.cairn.info/revue-afrique-contemporaine-2013-2-page-164.htm

[2] UNDP (2011). UNDP South-South learning Website, Published on 8 August 2011, http://south-south.undppovertycentre.org/news/item/497-growing-economic-powers-reinvigorate-south-south-co-operation , Accessed on 4 February 2014.

[3] White paper (2011). State Council Information Office of the People's Republic of China, 2011, "White Paper on China's Foreign Aid"

[4] Exim Bank (2013). The export import bank of China website,

[5] DCCI (2013). Dhaka Chamber of Commerce and Industry, http://www.dcci.org.bd

[6] (China Embassy in Bangladesh). Official website of Chinese Embassy in Bangladesh http://bd.china-embassy.org/eng/ , Accessed on 28 December 2013

[7] (ERD, Bangladesh). Website of Economic Relation Department/ERD, Ministry of Finance, Government of Bangladesh.

[8] (CCCE website).CCCE official website section.(http://www.ccceng.cn/En/news.aspx?CateID=39\&NewsCateID=39

[9] China Environmental Regulation by Ministry of Commerce and Ministry of Environmental Protection

[10] CBRC (2012). China Banking Regulatory Commission official website, Notice of the CBRC on Issuing the Green Credit Guidelines, http://www.cbrc.gov.cn/ Accessed on 16 November 2013 
[11] Islam, T. (2013), Research reports on "The Export and Import Bank of China and China Development Bank", an internal report for ActionAid International, as contribution to an international study on BRICS Development Banks and its policy implications to land tenure.

\section{Newspapers and magazines:}

[1] FE (2013).Govt takes \$1.5b hard loans to install five power plants', Financial Express, Published on Tuesday, 12 February 2013 , Reported by FHM HumayanKabir., Financial Express, Published on 20 June 2013, Accessed 5 February 2014, http://www.thefinancialexpress-bd.com/old/index.php?ref=MjBfMDZfMjBfMTNfMV8xXzE3MzY0OA

[2] BSS (2013). Bangladesh ShangbadShangstha, http://www1.bssnews.net/newsDetails.php?cat=7\&id=369152\$date=2013-1107\&dateCurrent=2013-11-10 Published on 7 November 2013, Accessed on 18 November 2013

[3] China Daily, (2012). Green-credit guideline for banks issued - Wang Xiaotian (China Daily, Updated: 2012-02-25) 